\title{
Over the moon or sick as a parrot? The effects of football results on a club's share price
}

Article

Accepted Version

Bell, A. R., Brooks, C., Matthews, D. and Sutcliffe, C. (2011) Over the moon or sick as a parrot? The effects of football results on a club's share price. Applied Economics, 44 (26). pp. 3435-3452. ISSN 1466-4283 doi:

https://doi.org/10.1080/00036846.2011.577017 Available at https://centaur.reading.ac.uk/20978/

It is advisable to refer to the publisher's version if you intend to cite from the work. See Guidance on citing.

To link to this article DOI: http://dx.doi.org/10.1080/00036846.2011.577017

Publisher: Routledge

All outputs in CentAUR are protected by Intellectual Property Rights law, including copyright law. Copyright and IPR is retained by the creators or other copyright holders. Terms and conditions for use of this material are defined in the End User Agreement.

www.reading.ac.uk/centaur 
Central Archive at the University of Reading

Reading's research outputs online 
This is an Author's Accepted Manuscript of an article published in Applied Economics (2012) [copyright Taylor \& Francis], available online at: http://www.tandfonline.com/10.1080/00036846.2011.577017 


\title{
Over the Moon or Sick as a Parrot?
}

\section{The Effects of Football Results on a Club's Share Price}

\section{Adrian Bell, Chris Brooks*, David Matthews and Charles Sutcliffe}

ICMA Centre, University of Reading

\begin{abstract}
This paper considers the impact of match results on the stock returns of English football clubs. We propose that the magnitude of the response to a given result depends on the importance of the game, which is measured in two ways. First, we consider the extent to which the clubs are close rivals vying for similar league positions, as winning such games is particularly significant. Second, we argue that each individual game becomes more important for those clubs likely to be promoted or relegated as the season draws to a close, since a given match will have increasing information content concerning the final league position of the club. Using a fairly large panel comprising data for 19 clubs, we find some support for the notion that stock prices are more affected by the results of important matches than matches of lesser importance. We also observe that the difference between the number of points the club secures from a given match, and the number it was expected to secure, affects its stock price, as does the number of goals that the club under question scores in the match, relative to its competitor.
\end{abstract}

September 2010

Acknowledgement: The authors are grateful for useful comments from two anonymous referees. The usual disclaimer applies.

\footnotetext{
* Correspondence to: Chris Brooks, ICMA Centre, University of Reading, Whiteknights, PO Box 242, Reading, RG6 6BA, UK, e-mail: c.brooks@icmacentre.rdg.ac.uk, Tel: +44 (0)118 378 8239, Fax: +44 (0)118 9314741
} 


\section{Introduction}

Football is well established as the most popular game on earth. ${ }^{1}$ In the late 80 s and early 90 s, with the introduction of the Premiership in England, a considerable number of clubs became limited companies, issuing equity for purchase by investors and fans alike. Football has developed an increasing economic importance over the past two decades, demonstrated by an increasing capital markets presence and the rapid growth in (particularly on-line) betting on match outcomes. This economic importance has been defined and stressed in the authoritative work by Dobson and Goddard (2001). Indeed the combined revenue of the top 20 clubs in the world has been estimated at $€ 3.9$ billion in the 2007/8 season - and this figure has trebled since 1996/7 (Jones, 2009, p.2). Football clubs represent a unique opportunity to study alternative explanations for share price movements, rather than explanations based on more standard business-related information that are the subject of much research on the pricing of equities and market efficiency. This arises since club shareholders comprise both conventional investors motivated purely by returns, and club fans who arguably care less about making money but also hold the shares for sentimental reasons. If football results are price sensitive information, testing whether they have an impact on stock prices represents a test of semi-strong form of efficiency.

There is thus a need to investigate whether football results are indeed price sensitive information. As a club becomes more successful, its players expect to receive substantial pay rises (and win bonuses). This will eat up part or all of the extra revenue generated by winning, although of course by winning, players reveal their quality and increase their value in the transfer market. There is also the concern that a single result may be too insignificant to have a measurable effect on the club's share price, after allowing for the high transactions costs of trading shares in football clubs. Palomino, Renneboog and Zhang (2009) report that the bid-ask spread for UK football clubs varies from $1.6 \%$ for Manchester United to $15.4 \%$ for Sheffield United (see Table 3 for values of the bid-ask spreads for our sample of clubs).

While football results are not cash flows, they are expected to affect the share price of football clubs because winning games is likely to increase the club's subsequent cash flows and value via a number of routes. These may include bigger attendances at games (assuming no capacity constraint), higher ticket prices, higher prices for leasing stadium boxes, increased advertizing revenue, greater sponsorship income and merchandise sales, higher revenue from TV deals and radio commentary on games, higher payments from the league according to their finishing place, increased prize money from cups, and increased revenue from associated businesses.

\footnotetext{
${ }^{1}$ Although much hyperbole is written on this, such as this example from a popular sports website,http://www.sportingo.com/football/a9387 why-football-beautiful-game-most-popular-sport-world, accessed 27/6/09, it is clear that such a statement is defensible. For instance, the World Cup finals in Germany in 2006 were watched by a cumulative audience of over 26 billion from 214 countries (http://www.fifa.com/mm/document/fifafacts/ffprojects/ip-401_06e_tv_2658.pdf, accessed 27/6/09) and the Premiership in England appeals to a global audience (http://news.bbc.co.uk/sport1/hi/football/eng_prem/7232378.stm , accessed 27/6/09).
} 
There is empirical evidence to support a strong link between results and club revenues. Szymanski and Kuypers (1999, pp. 186-193) demonstrate that the revenues of English clubs are largely determined by league position, while Bernile and Lyandres (2008) found that winning European Champions League and UEFA Cup games has a positive effect on a club's return on assets. Barajas, Fernandez-Jardon and Crolley (2007) show that for Spanish football clubs, success on the pitch has a positive effect on club revenues. In addition, Pinnuck and Potter (2006) discovered that match day receipts, membership receipts, sponsorship and other marketing receipts for the Australian Football League are a positive function of winning games.

Football results are a particularly good type of information to study because, with games played in the evening and at weekends, stock markets are closed when the information arrives. This means that the market should open at a new price that incorporates the information content of the result. In addition, there are frequent signals (for instance, 38 Premiership results per year); the information is not known to insiders before it is published (assuming that football matches are not fixed) so there cannot be informed pre-release trading; the information is quantified (goals, points); the time the information arrives is clear (about two hours after kick off); results are available the moment the final whistle blows, and are immediately and widely publicised via the media. Finally, betting odds are available to quantify market expectations of the result enabling the surprise element of each signal to be computed in an uncontroversial way.

This is the first study to use surprises based on betting odds expressed in league points to study English football results. It also employs two novel measures of the significance of each game, which enables us to test whether the market responds more strongly to match results when the game may be considered important. The two measures are based on the extent to which the two clubs are rivals within their league, and the proximity of the match to the end of the season. We find some support for the notion that important games generate greater reactions in stock prices. This study also includes goal difference surprises as a novel type of match information, and uses a multiplicative specification, in addition to a linear functional form.

The remainder of this paper is organised as follows: Section 2 summarises the previous literature, and Section 3 explains the methodology used in this study. Section 4 sets out the models tested, while Section 5 describes the data. Finally the results appear in Section 6, and Section 7 concludes.

\section{Previous Literature}

One of the earliest studies of the effects of team sports results on the share price was for the Boston Celtics, an American basketball team, by Scherr, Abbott and Thompson (1993). They found that the club's share price rose on a win and fell on a loss, particularly during the end of year championship deciders. A subsequent study of the Boston Celtics by Brown and Hartzell (2001) used point spread betting odds to control for market expectations before the game, while the Centre for Research in 
Security Prices (CRSP) index was used to control for market-wide effects. They found that wins increased, and losses reduced, the club's share price. In addition, there was a smaller absolute response to wins than to losses, and playoff games evoked a larger absolute price response.

Even in the absence of any direct effects on company cash flows, football results can affect stock prices by changing the mood, confidence, and emotional state of investors. For example, international football results have been shown to affect national stock market indices, even though there is minimal aggregate effect on a country's companies (Ashton, Gerrard and Hudson, 2003; Dohmen, Falk, Huffman and Sunde, 2006; Edmans, Garcia and Norli, 2007; Kaplanski and Levy, 2008, and Tufan, 2006). Berument and Yucel (2005) found that when Fenerbahce won a game in a European competition, the growth rate of Turkish industrial output increased, while Berument, Ceylan and Gozpinar (2006) found that a win by Besiktas in European competition led to a rise in the Turkish stock market. Football results have also been shown to influence the medical, social and political behaviour of supporters (Carroll et al, 2002, Kaplanski and Levy, 2008, Kirkup, 2003, Wilbert-Lampen, 2008, Witte et al, 2000). This raises the possibility that results may affect the club's share price indirectly via non-economic routes, as well as by a direct effect on the club's cash flows. For example, after a win, supporters may become more optimistic, more confident of their abilities, and less risk averse, making them more willing to buy risky shares, with reverse effects after a loss (Kaplanski and Levy, 2008). Any non-economic effects may tend to reinforce the cash flow effects of football results. In the light of such non-economic effects and the sentimental attachment of supporters to their clubs, it is sometimes suggested that football investors may make emotional rather than rational decisions, although all that is required for market efficiency is that the marginal investor is rational. Given the lack of liquidity in the shares of some of the smaller clubs, as we detail below, the proportion of shareholders who are fans is likely to be lower than for the larger clubs. Since fans are unlikely to sell their shares and desert their club following a run of poor performance on the pitch, we may expect to observe a stronger price reaction following results for the bigger clubs such as Manchester United. A run of poor match form may be seen as indicating lower future revenues and therefore profitability, which may cause shareholders who are concerned only with money and have no emotional attachment to the club to sell their shares.

The following discussion will classify research on the effects of European soccer results on club share prices by the method used by the studies to measure the signal to which the market is reacting. Early studies used the raw results - win, lose or draw, with no allowance for market expectations. Later, more sophisticated studies used a forecasting model to estimate market expectations and included a surprise variable. Other studies have refined the methodology and used betting odds to compute the implied probabilities of the various results, which were then converted into either dummy variables or surprises expressed in league points. It should be noted that these studies are on the whole based on English football clubs, but this perhaps reflects both the popularity of the English football league (and the Premiership in particular), alongside the relatively large number of listed clubs and the availability of a wealth of historical game and betting data. 


\section{a. Raw Results}

The first study of the effects of football results on the club's share price was by Morrow (1999), who analysed data spanning six months on Sunderland and Manchester United. After controlling for marketwide effects, wins increased, and losses reduced, the club's share price. A subsequent study by Renneboog and Vanbrabant (2000) examined 17 British football clubs for three seasons, controlling for market-wide effects. Wins had a positive effect, and losses a negative effect on the club's share price, with losses having a bigger absolute effect. The price impact was larger for games played after $15^{\text {th }}$ February in each season, which was interpreted as a proxy for promotion and relegation games. Amir and Livne (2005) considered 1,348 UK football games for 24 listed clubs, and showed that wins were associated with a price rise, and losses with a share price fall. Data on 16 British football clubs for three seasons was used by Palomino, Renneboog and Zhang $(2005,2009)$. They found that share prices were a positive function of either goal difference or winning. Data on Sporting Lisbon and Porto was examined by Duque and Ferreira (2008) for five seasons, and they found that a win for Sporting led to a rise in the share price, after controlling for movements in the Portuguese stock market, while a draw or loss led to a drop. Fotaki, Markellos and Mania (2009) employed data on 15 UK clubs for seven seasons and showed that, after controlling for market-wide effects, wins led to a price rise, and defeats to a price fall. Using data for the 2006-7 season on 18 European clubs, Benkraiem, Louchichi and Marques (2009) found that defeats led to price falls. Finally, Benkraiem, Le Roy and Louchichi (2010) analysed data for the 2006-7 season on seven English and Scottish clubs and discovered that the volatility of a club's share price increases on the day after a game, which implies that match results are price sensitive information.

\section{b. Forecasting Model}

Dobson and Goddard (2001) used data for 13 English football clubs for two seasons, together with the FTSE 100 index to control for market-wide factors, their own forecasting model to proxy market expectations of the football result, dummies for promotion and relegation games, BSkyB dummies for the bid for Manchester United, and cup elimination dummies. Unexpected good news increased the club's share price, while unexpected bad news reduced the share price. In addition, promotion increased the club's share price, and relegation or elimination from a European cup competition reduced the club's share price. The FTSE 100 index was used to control for systematic risk by Gannon, Evans and Goddard (2006), together with a forecasting model to get unexpected results for six clubs, and a range of dummies to remove the effects of various club-specific events (chiefly take-over bids). Unexpectedly good football results generally had a positive effect on the share price (and vice versa), while the BSkyB

purchase of the Premiership TV broadcasting rights in both 1996 and 2000 had a positive effect on the share prices of Manchester United and Tottenham Hotspur in 1996, but had no effect on the share price of any club in 2000 .

\section{c. Implied Probabilities and Dummies}

Zuber, Yiu, Lamb and Gandar (2005) considered 10 English Premiership football clubs for three seasons 
with dummy variables representing a home or away game, a surprise loss or surprise win, a cup or league game, and whether the club was currently in the top five or the bottom three of the Premiership. The betting odds were used to compute two binary surprise variables: the win surprise dummy is one when the club is expected to lose, but actually wins. In addition, FTSE index and goal difference variables were included in the regressions. The only significant finding was that cup games had a positive effect on the share price, with no significant effects for the unexpected win and loss variables.

Betting odds were used by Palomino, Renneboog and Zhang (2009) to construct four dummy variables representing a weak or strong probability of victory or defeat for each UK football game. Unusually, the market rose most when a strongly expected win occurred, and rose least when a loss was strongly expected, but the result was a win. However, this analysis did not control for other factors. A multicountry study was conducted by Scholtens and Peenstra (2009), who analysed data on eight football clubs from five countries (England, Germany, Italy, Netherlands, Portugal) for four seasons. After using a stock market index to remove systematic factors, they found that expected and unexpected wins (computed following Palomino et al, 2005, 2009) resulted in a share price rise, while expected and unexpected losses led to a share price fall. The price response to wins was smaller than for losses.

\section{d. Implied Probabilities and League Points}

In the first study to use betting odds to compute implied probabilities and to create a continuous surprise variable expressed in league points, Stadtmann (2006) investigated Borussia Dortmund of the Bundesliga. Using data for four years, he found that surprise points had a positive relationship with the club's share price.

To summarise, there is now overwhelming evidence of a relationship between football match results and stock prices. But this literature has used a linear specification in which all match results are treated as representing equally important information. It is our contention that match results should be weighted by the importance of a particular match.

\section{Methodology}

In contrast to many previous studies, it will be argued that daily returns on football club shares should depend on just the surprise component of results, the goal difference, the importance of these surprises, a market index and other events relevant to the club's share price but unrelated to football results.

\section{A. Surprise Results}

The efficient market hypothesis requires that a club's current share price should reflect all the information available to investors, including the expected results from prospective games (assuming this is price sensitive information). For any particular game, this information includes variables such as whether the game is at home or away, player availability, the identity of the referee and the two managers, the recent form and morale of both teams, the likely team tactics, and the probable state of the 
pitch. When the result of the game is known, the share price should adjust to reflect its unexpected component. Therefore, all the information that affects the result of a game should be contained in market expectations, which can be proxied by the betting odds. ${ }^{2}$ In consequence, there should be no pricing role for variables such as home or away in a regression equation explaining share returns.

In order to quantify the relationship between match results and stock prices, the unexpected result must be converted into a change in the club's expected cash flows, and hence stock returns. To accomplish this, following Stadtmann (2006), a linear relationship is assumed between league points and cash flows, and surprises are converted into their league points equivalent, using three points for a win, one point for a draw and zero points for a defeat. The probability $(q)$ of winning a particular bet with winnings of $w$ in return for a stake of $s$ is $q=s /(w+s)$. However, such probabilities include the bookmaker's profit, or overround (usually about $11.5 \%$ or $12 \%$ - see Braun and Kvasnicka, 2008, Deschamps and Gergaud, 2007, Dobson and Goddard, 2001, p. 405, Forrest, 2008). This is removed to give the implied probability of a particular outcome (win, lose or draw), $p_{i}$ :

$$
p_{i}=\frac{q_{i}}{\sum_{i=1}^{3} q_{i}}
$$

The expected league points for a club from a game are $E P=3 p_{\text {win }}+1 p_{\text {draw }}+0 p_{\text {loss }}$ and so the surprise league points $(S)$ are

$\begin{array}{ll}\text { Win: } & S=3-E P \\ \text { Draw: } & S=1-E P \\ \text { Loss: } & S=0-E P\end{array}$

Football betting is unusual, compared to horse racing for instance, in that the odds are fixed by bookmakers on Monday for games during the subsequent weekend and the following Monday, and published on Wednesday night or Thursday morning (Palomino, Renneboog and Zhang, 2005, 2009). These odds do not change in response to the weight of money bet on particular outcomes. The objective of bookmakers in setting odds is not to forecast the result, but to maximise their profits. Therefore, the odds may contain biases designed to exploit the preferences of bettors - for example, the favouritelongshot bias and the sentimental attachment of bettors to particular clubs. Bernile and Lyandres (2008), Cain, Law and Peel (2000), Deschamps and Gergaud (2007), Graham and Stott (2008), Makropoulou and Markellos (2007) and Vlastakis, Dotsis and Markellos (2009) have found evidence supporting a favourite-longshot bias in football odds, with the odds on longshots (high scores) being unfavourable to the bettor, relative to the odds on the favourite (low scores), while Dixon and Pope (2004) and Dobson and Goddard (2001, p. 408) found a reverse favourite-longshot bias, and Franck, Verbeek and Nuesch (2008) found no evidence of a favourite-longshot bias.

\footnotetext{
${ }^{2}$ Other information besides the result can arrive during a game - for instance, a key player suffers an injury or is sent off, or the team plays very well and wins by a big margin. It is assumed that, excluding the score, the information generated during the game has, on average, no effect on the club's share price.
} 
It is also possible that, where transactions costs are high enough to prevent arbitrage, sentiment among football supporters leads them to bet on their club to win, with little regard to the odds offered. This results in bookmakers setting biased odds to allow for the predicted weight of money. Forrest and Simmons $(2005,2008)$ tested this using data on English, Spanish and Scottish football betting, and found that more favourable odds were offered on clubs with the greater number of supporters. Using data for 12 countries competing in the Euro 2008 qualifying games, Braun and Kvasnicka (2008) discovered the odds were biased both up and down to allow for the sentimental views of particular nationalities. Over the 2000-2008 period Frank, Verbeek and Nuesch (2008) studied the effects of sentiment on the odds offered on games in the top four English leagues, and showed that bookmakers offered better odds on well-supported clubs. Bernile and Lyandres (2008) found that the odds from betting exchanges ${ }^{3}$ on European Champions League and UEFA Cup games are biased by the optimism of supporters of the clubs, while the odds from bookmakers are not. Whatever the direction of any bias, if the odds are a biased predictor of the match result, the surprise variable will also be biased. We therefore examine in Section 6 the extent to which the odds are a biased predictor of results.

Since the odds are fixed and do not change in response to new information or the pattern of bets placed, their ability to accurately represent stock market expectations, as reflected in the closing price before the game, is open to question. To the extent that new information arrives after the odds have been set, they become a less accurate predictor, increasing the size of the measured surprises. Spann and Skiera (2009) compared the accuracy of fixed odds with that of tipsters and prediction markets ${ }^{4}$ in forecasting the results of 837 German soccer league games. They discovered that the fixed odds and the prices from the prediction market had similar forecasting accuracies, and both were markedly superior to tipsters. Since tipsters and prediction markets can use information that arrives after the odds have been set, this suggests that little useful information arrives after the odds have been chosen.

A number of researchers have compared the ability of the odds to forecast results with that of an econometric model. For the 1999-2000 and 2000-1 English seasons, Goddard and Asimakopoulos (2004) and Forrest, Goddard and Simmons (2005) found that an econometric model contained information not in the odds. However, for the 2001-2 and 2002-3 English seasons, the odds setters had improved, and the odds were superior to an econometric model in forecasting football results (Forrest, Goddard and Simmons, 2005). Pujol (2008) found that during each season, the ability of Spanish bettors to forecast football results improves during the season. This is probably due to the revelation of additional information on team abilities as the season unfolds, and implies that the accuracy of the odds set by bookmakers improves during the season. Graham and Stott (2008) used English data for five

\footnotetext{
${ }^{3}$ The odds in a betting exchange are set by the interplay of demand and supply of contracts by customers, with the betting exchange merely providing a marketplace.

${ }^{4}$ In a prediction market aggregate market expectations are revealed by trading virtual stock on the various outcomes.
} 
seasons (2001-2006) to compare the performance of the odds in forecasting results with that of an econometric model, and found little difference in the accuracy of the two approaches. These results suggest that, at least in recent years, the odds have an accuracy that cannot be beaten by econometric models. It is possible that, when they are announced, the odds contain information not impounded into the share price because the odds setters devote considerably greater resources to predicting the result of the next game than do bettors. In which case, the announcement of the odds should move the share price. Palomino, Renneboog and Zhang $(2005,2009)$ found no such price reaction, implying either that the odds contain no new information large enough to cover the transactions costs of trading, or that the market is semi-strong inefficient and ignores the odds. Whether or not there is a price response to the announcement of the odds, their publication several days before the game, coupled with their accuracy (relative to an econometric model) should help ensure that the pre-game share price reflects the available public information.

\section{B. Importance}

The magnitude of the share price response should depend on the importance of the result for the club's value. Some results may be of little consequence - for example, games after the club faces certain relegation, and so have a very small effect on the share price, while others may be crucial, such as a win which avoids relegation. Therefore the share price reaction depends on both the direction and magnitude of the surprise and the importance of this surprise for the value of the club. Importance can be measured along two dimensions: (a) rivalry - a "six pointer" game against a close rival who is expected to end the season in a similar league position, and (b) final position - any game towards the end of the season, if it is becoming increasingly clear that every point is vital to avoid relegation, gain promotion or win the Premiership. The measurement of rivalry and final position will now be considered.

\section{i. Rivalry}

The degree of rivalry between two clubs is defined as the expected difference in their final league positions. ${ }^{5}$ This can be proxied using the absolute difference in the weighted sum of their final league positions last season, and their current league positions. The weighted sum for club $j$ at time $i\left(W_{i j}\right)$ is computed as:-

$$
W_{i j}=R L_{j}[(2(N-1)-i) / 2(N-1)]+R C_{i j}[i / 2(N-1)]
$$

where $N$ is the number of clubs in the league, e.g. 20;2(N-1) is the total number of league games played in the current season, e.g. 38; $i$ is the number of the current game for the club (which starts at 1 and ends with $2(N-1)$ ); $R L_{j}$ is the final position of club $j$ in the league at the end of the previous season; $R C_{i j}$ is the position of club $j$ in the league this season just before this game. At the start of the season $W_{i j}$ is just last

\footnotetext{
${ }^{5}$ Note that our definition of rivalry is different to the common use of this term in football to mean historical competition between two, typically local, clubs. For instance, the "Merseyside derby" between Liverpool and Everton.
} 
year's league position. As the season progresses $W_{i j}$ gradually morphs into the current year's final league position.

The rivalry measure for game $i$ between clubs $A$ and $B$ is $R V_{i}=\left(N-\left|W_{i A}-W_{i B}\right|\right)$ which has a maximum value of about 19 when the two clubs are deadly rivals, and a minimum value of one when they are the top and bottom clubs. For clubs newly promoted to the Premiership, their league positions for last season are 18,19 or 20 , as they replace the relegated clubs.

\section{ii. Final Position}

It can be argued that the market seeks to predict the future cash flows of the club, and the final league position is an important determinant of the club's future cash flows. Therefore, the effect of a result on the final league position is important. While forecasting the outcome of any single game is risky, over the season, a club's aggregate results tend to be more predictable. Therefore, the main risk for the top clubs is not whether they are relegated, but whether they win the Premiership or qualify for the Champions League, and this risk is usually resolved only towards the end of the season. A similar argument applies to the bottom clubs and relegation. Therefore, as the season progresses, results tend to resolve more uncertainty about the club's final league position than those in the early part of the season.

Some previous authors have chosen to include dummy variables in the regression equation to proxy for the way that, for some clubs, games towards the end of the season are vital for securing promotion or avoiding relegation. Renneboog and Vanbrabant (2000) included a dummy variable for all games after $15^{\text {th }}$ February for clubs in the promotion or relegation zones, while Palomino, Renneboog and Zhang (2009) split the season into games played before and after $1^{\text {st }}$ April (or $1^{\text {st }}$ March, or $1^{\text {st }}$ May). Palomino, Renneboog and Zhang (2005) looked separately at the April-June games of the top six and the bottom six clubs, and Zuber, Yiu, Lamb and Gandar (2005) included dummy variables for clubs currently in the top five or the bottom three. Audas, Dobson and Goddard (2002) used two 0-1 variables to denote differences in the importance of a game to the home and away clubs. They treated a game as important to a club if, before the game, the club could be promoted or relegated, assuming all other clubs receive one point from each of their remaining games. ${ }^{6}$ These dummy variables may be helpful in identifying games with a major difference in incentives between the clubs, but are much less useful in identifying the most important games for a particular club.

The approach used in this paper is to model the increasing importance of results for clubs as the season proceeds in a way that avoids the need to specify a specific start date for results becoming more

\footnotetext{
${ }^{6}$ The choice of one point for the remaining games is arbitrary, and likely to be an underestimate for clubs seeking promotion.
} 
important or discrete promotion and relegation zones. Instead of a zero-one effect for the first and second parts of the season, it is assumed that final position importance increases steadily over the season. This can be modelled using non-linear weights that steadily decrease throughout the season as the amount of uncertainty about the final league position also diminishes. We adopt a function of the following form for game $i$ :

$$
Y_{i}=1 /(1+i)^{Q}
$$

where $i$ is the number of games played and $Q$ is chosen to reflect the degree to which uncertainty resolution increases during the season. The greater is $Q$, the less diverse are the weights, and in the empirical analysis below, we set $Q=0.5$ so that equation (4) involves a square root function. To avoid the need to specify whether a club is in some specified promotion or relegation zone, $Y_{i}$ is weighted by the extent to which the club's weighted league position differs from the mean.

$$
\mathrm{Z}_{\mathrm{i}}=\left|C_{k}-W_{i j}\right|
$$

where $C_{k}$ is the mean league position for league $k$, i.e. $\left(N_{k}+1\right) / 2$. The overall final position variable is given by $F_{i}=Y_{i} Z_{i}$.

\section{Goal Difference}

While the result has a direct effect on league points, the size of the goal difference may alter expectations of the club's results in subsequent games. For example, depending on the opposition, a 5-0 victory indicates the team is playing well and this bodes well for the next few results, with their associated league points. To control for pre-game expectations of the goal difference, a goal difference surprise variable is created. This is computed relative to the benchmark of the club's average goal difference in the five previous games.

\section{Other Factors}

Various other factors might affect a football club's share price besides football results. For example, the share price may be affected by player transfers and contract renewals, a change of manager, sponsorship deals, TV rights deals, a new stadium, take-over bids for the club, football rule changes such as Bosman in 1995, the announcement of the company's earnings, general movements of the stock market, and exdividend dates.

Previous researchers have investigated the price effects of some of these factors for football clubs. For example, Stadtmann (2006) found that player transfers and contract renewals did not affect the club's share price. Fotaki, Markellos and Mania (2009) discovered that sales or loans of players have a positive effect on stock prices, while acquisitions have a negative effect after the announcement period.

Dobson and Goddard (2001) studied 981 English managerial spells between 1973-99. They found that a 
change of manager had a negative effect on performance for the next game, but a positive effect on performance in the next season. Audas, Dobson and Goddard (2002) looked at the effect on results of voluntary and involuntary within-season changes of manager. Analysing data on 736 managerial changes for English football clubs over the 1972-2000 period, they discovered that a change of manager led to a $1 \%$ increase in the probability of losing the next game, and a $0.4 \%$ increase of losing the subsequent game. Data for 18 Dutch football clubs were investigated by Koning (2003), and he concluded that changing the manager did not affect team performance, which suggests that it should not affect the club's share price. Bruinshoofd and Ter Weel (2003) analysed managerial changes for 12 years in the Dutch football league and found that replacing the manager did not lead to improved results, and Ter Weel (2006) used data for 18 seasons of Dutch football to reach a similar conclusion. Dios Tena and Forrest (2007) used Spanish football data and showed that a change of manager had no effect on away results, although it produced a modest improvement in home results, while Frick and Simmons (2008) found that changing the manager in the Bundesliga during the season lowered the club's league points for that season. A more recent study by Fotaki, Markellos and Mania (2009) demonstrated that 51 changes of manager by UK clubs had no effect on the share price of the club concerned. Overall, these studies suggest that managerial change does not have a substantial effect on the club's share price.

Baur and McKeating (2009) examined the effect of being listed on a stock exchange on the football results for 22 European clubs over a period of 19 years. There was no effect on results against foreign opposition, nor on the domestic results of clubs in the top division of their league. These findings suggest that being listed does not affect a club's share returns as it does not affect football results. Spais and Filis (2008) considered the announcement in March 2007 of the sponsorship of Juventus by Fiat, and concluded that, if anything, this reduced the Juventus share price.

These empirical results support the view that player transfers and loans, contract renewals, changes of manager and sponsor and being listed on an exchange do not have a substantial effect the club's share price and need not be included in a regression equation to explain movements in a club's share price.

In accordance with the capital asset pricing model (CAPM), previous researchers have usually found that general stock market movements affect a club's share price. In addition, it is widely believed that company share prices are affected by the announcement of company earnings, although this has not been tested for football clubs. This lack of inclusion of announcements may be because they are unlikely to have a significant effect on stock returns. First, most football games occur over the weekend when earnings announcements are unlikely, thereby avoiding any interaction between games and announcements. Second, if a football game does coincide with an earnings announcement, their separate effects on returns will have a very low (or zero) correlation. 
As well as earnings announcements, variables for take-over bids and TV deals are also omitted. Excluding an explanatory variable which has a significant effect on the dependent variable leads to omitted variable bias. This causes the estimated coefficients for the included explanatory variables to be biased, unless the explanatory variable has zero correlation with the omitted variable. In addition, omitted variable bias inflates the estimated standard errors for all the estimated coefficients, reducing their apparent significance. Therefore, while the estimated coefficients on the other explanatory variables (and constant) are biased, their coefficients will be unbiased due to their lack of correlation with earnings announcements, take-over bids and TV deals. In summary, when omitting such factors, the estimated coefficients on the surprise and goal difference variables will remain unbiased. The current research is not concerned with estimating the coefficients on the other explanatory variables, only with controlling for their effect on the dependent variable and we therefore follow previous research in excluding such factors.

\section{Models}

Two possibilities were examined for the speed of response of the stock market to the result. First, returns from the closing price before the game to the first closing price after the game are studied. This gives the market a day's trading to incorporate the surprise into the share price. Second, a lag of one day is analysed, allowing two days for the market to respond.

The discussion in section 3 indicates that football club returns should be influenced by general stock market movements (proxied by a market index), the surprise component of football results (expressed in league points) weighted by the rivalry score and closeness of the game to the end of the season, the goal difference surprise (weighted by the rivalry score), and other non-league game events. The points surprise, rivalry score and the proximity to the end of the season will be modelled as affecting the share price in both a multiplicative and additive manner. The multiplicative model interacts the points and goal surprise variables with the two importance measures (rivalry and proximity to the end of the season). Our argument is that the impact of points and goal surprises will be greater when the match is an important one and the multiplicative specifications allow for this. We also include three variables the earlier theory suggests should not be significant - $G A_{t}$ is the actual (as opposed to unexpected) number of goals ahead of the club under consideration; $H_{t}$ is a dummy taking the value 0 for home games and 1 for away games; and $E P_{t}$ is the expected number of points calculated from the average betting odds. The formulations to be fitted are:-

$$
\begin{aligned}
& R_{t}=\alpha+\beta_{1} M_{t}+\beta_{2} S_{t} F_{t} R V_{t}+\beta_{3} G S_{t} R V_{t}+\varepsilon_{t} \\
& R_{t}=\alpha+\beta_{1} M_{t}+\beta_{2} S_{t} F_{t}+\beta_{3} G S_{t} R V_{t}+\varepsilon_{t} \\
& R_{t}=\alpha+\beta_{1} M_{t}+\beta_{2} S_{t} R V_{t}+\beta_{3} G S_{t} R V_{t}+\varepsilon_{t}
\end{aligned}
$$


$R_{t}=\alpha+\beta_{1} M_{t}+\beta_{2} S_{t} F_{t} R V_{t}+\beta_{3} G S_{t} R V_{t}+\beta_{4} G A_{t}+\beta_{5} S_{t} H_{t}+\beta_{6} G S_{t} H_{t}+\beta_{7} E P_{t}+\varepsilon_{t}$

$R_{t}=\alpha+\beta_{1} M_{t}+\beta_{2} S_{t-1} F_{t-1} R V_{t-1}+\beta_{3} G S_{t-1} R V_{t-1}+\varepsilon_{t}$

where $R_{t}$ is the close to close return on the club's shares, $M_{t}$ is the return on the market index, $S_{t}$ is the surprise component of the club's football results during the closed market period, $R V_{t}$ is the rivalry score for this game, $F_{t}$ is closeness to the end of the season, and $G S_{t}$ is the goal difference surprise.

We also employ an additive formulation of the model:-

$\mathrm{R}_{\mathrm{t}}=\alpha+\beta_{1} M_{t}+\beta_{2} S_{t}+\beta_{3} F_{t} D_{t}+\beta_{4} R V_{t} D_{t}+\beta_{5} G S_{t} R V_{t}+\beta_{6} G A_{t}+\beta_{7} S_{t} H_{t}+\beta_{8} G S_{t} H_{t}+\beta_{9} E P_{t}+\varepsilon_{t}$

with all notation as above, and $D_{t}$ is a dummy variable that takes the value +1 when the point surprise is positive, and 0 when the surprise is negative.

The surprises and goal difference from non-league games (FA Cup, Worthington or Carling League Cup, UEFA Cup, European Championship, Intertoto Cup, Super Cup) have not been included in the model for several reasons. First, betting odds were not available for these games. Second, league points cannot be used to quantify the effect of a surprise on club value. Third, cup results appear to have less effect on club valuation (as evidenced by top clubs fielding weakened teams in cup games, other than the Champions League). Finally, there are usually only a few games in each non-league competition, making it hard to estimate the effect of such games on the share price with any precision. We have therefore adopted a procedure equivalent to using separate dummy variables for every nonleague game to ensure that our findings are not affected by the results of cup games.

\section{Data}

The data cover match results for quoted English football clubs between the start of the 2000/01 season and the end of the 2007/08 season - a total of 5,187 games covering 19 clubs. The football scores and betting odds were sourced from www.football-data.co.uk. Some of the clubs were listed on a stock exchange for only part of this period, and so their share price cannot be obtained throughout the period. For example, Chelsea was delisted in 2003 when Roman Abramovich bought the club. Table 1 shows the dates for which share prices are available for each club.

The corresponding betting odds for each game were obtained for 11 bookmakers: Bet 365, Bet and Win, Gamebookers, Interwetten, Ladbrokes, Sporting Odds, Sporting Bet, Stan James, Stanley Bet, VC Bet and William Hill. The weekend match odds, including Mondays, were collected on the preceding Friday, and the mid-week match odds were collected on Tuesdays. The simple arithmetic average of the available odds from these bookmakers was used to give the home win, away win and draw odds for each game. 
The individual pre-game, match-day information (final league position, league position on the day before the game, and the number of games played) was obtained from the Association of Football Statisticians' Football Genome Project table generator at www.11v11.com. Daily financial information (closing price, opening price, total return, market value, number of trades, and turnover by volume, together with the FTSE 100 index) on every club examined was collected from Datastream. We employ the FTSE 100 index as a proxy for the market portfolio.

In order to ensure that the estimation results are not unduly influenced by non-match information, we included dummy variables for any day's returns which are more than six standard deviations from their mean values, and for which a relevant news item can be found (e.g. a take-over rumour or such a rumour being quashed). Dummies are therefore included for Leeds (1 December 2003), Sunderland (2 dummies: 7 and 8 July 2004) and Watford (3 dummies: 25 and 26 September 2002 and 9 April 2006). An example of one of these outliers will demonstrate the other kinds of events that can move the share price. On 1 December 2003, shares in Leeds United rose by $68 \%$ in a single day. This can be rationalised by the attempted takeover by Sheikh Abdul bin Mubarak Al-Khailifa of Bahrain, as reported in the Guardian, but quickly dismissed by the club board, rather than any football-related explanation. $^{7}$

\section{Results}

For each game, the average probabilities of the three possible outcomes implied by the odds were compared with the average ex post frequencies for the 5,187 observations. Table 2 shows that the betting odds and the corresponding average of actual outcomes are extremely close for all three of the home win, away win and a draw. ${ }^{8}$ This lack of bias accords with the results of Kuypers (2000) for the English 1993-4 and 1994-5 seasons.

Table 3 presents summary statistics for the stocks of the 19 English clubs in the data set. Aside from Manchester United, which is almost ten times bigger than the next largest stock at over $£ 500$ million, the typical market capitalisation (measured over the period for which we have data for that club) is around $£ 10$ million, ranging from $£ 5$ million (Preston) and $£ 5.2$ million (QPR) to Newcastle ( $£ 58$ million) and Tottenham ( $£ 54$ million). Column 3 of Table 3 gives a measure of trading activity for the shares, and is the percentage of weekdays in the sample for which there is no trading, including public holidays. It is evident that the shares of Chelsea, QPR, Leeds, Manchester United, Millwall, Newcastle

\footnotetext{
${ }^{7}$ http://www.guardian.co.uk/football/2003/dec/01/newsstory.sport8

8 Exposing this to a formal statistical test for the significance of the difference between the odds and the actual results is fraught with difficulty in our case because one of the series is continuous but bounded between 0 and 1 , while the other is a binary variable. Given that the actual and expected numbers are so very close, for the purposes of this paper we feel able to draw firm conclusions without conducting a formal statistical test.
} 
and Tottenham have reasonably active markets, at least by this measure. On the other hand, for Preston, West Brom, and Watford, there were no trades at all on more than half of weekdays during the sample.

A further indication of the stocks' liquidities, or lack thereof, is given in the penultimate column of Table 3, which shows the value of the daily volume. This reveals that liquidity in most of these stocks is low. For Charlton, QPR, Nottingham Forrest, Preston and Watford, a £3,000 trade would be larger than the entire mean daily trading value for those companies. In addition, as shown in the final column of the table, the bid-ask spreads for the smaller clubs (e.g., Preston or Millwall) are of the order of 5-20\% of the mid-price, while for Watford, the spread averaged more than $30 \%$ of the mid-price over our sample period. Only Manchester United stock has a modest spread at less than $2 \%$ of the mid-price. The evidence suggests that some football clubs typically suffer from a lack of liquidity and high trading costs, and these frictions may preclude the rapid incorporation of new information into share prices.

Table 4 presents the results from estimating equation (6), where the points surprise variable is interacted with the two measures of importance (closeness to the end of the season and the degree of rivalry between the clubs), and the goal surprise variable is interacted with the rivalry measure. To account for the impact of general stock market movements on the clubs' share prices, we also include the return on the FTSE 100. The final rows of this and all subsequent tables show the results from an identical analysis of a pooled sample of data from all 19 clubs.

Table 4 shows that $\beta_{1}$, the estimates of the response to the market index, is positive for 14 clubs and statistically significant for seven of them. However, the magnitudes of the coefficients are of the order 0.1-0.2 or even smaller in some cases, indicating that football club share prices are not strongly influenced by general stock market movements - perhaps because the revenues from running football clubs are not much affected by the business cycle. For the pooled sample, the stock market index return has a highly significant but small effect.

The coefficient on the interacted points surprise variable $\left(\beta_{2}\right)$ is positive for all but one club, and is statistically significant at the $5 \%$ level or higher for 11 of them, and for the pooled sample. However, the coefficient on the interacted goal surprise variable $\left(\beta_{3}\right)$ is only significant at the $5 \%$ level for three clubs with a negative sign, and at the $10 \%$ level with a positive sign for a further one. This suggests that the market focuses more on points surprises than goal surprises when assessing the impact of match results on equity valuations. The negative sign on the interacted goal surprise variable appears counterintuitive at first sight, but in forming our measure of the expected goal difference, we used as a benchmark the average goal difference in the previous 5 games. This may be an inadequate proxy- for example, because the "true" expected goal difference is zero. Hence the number of goals ahead is really 
the "true" measure of the goal surprise, while $G S$ is a biased measure as it is using the wrong benchmark.

We also repeat the analysis of Table 4, but this time interacting the points surprise with only the proximity to the end of the season (equation 7 ) and only with the rivalry score (equation 8 ) respectively rather than using both variables together multiplicatively. In general, these specifications share the same key features as Table 4, and so are not shown in the interests of brevity.

Table 5 repeats the analysis of Table 4, but now including several variables that, according to the efficient markets hypothesis, should not affect stock returns since their impacts are either already incorporated into other variables, or they are thought to be irrelevant. The extra variables included in equation (9) are: $G A_{t}, S_{t} H_{t}, G S_{t} H$, and $E P_{t}$. Focusing attention on the parameters attached to these additional variables, Table 5 shows some role in stock pricing for the number of goals ahead $\left(\beta_{4}\right)$ and the surprise points $\times$ home dummy $\left(\beta_{5}\right)$, but not for the goals surprise $\times$ home dummy $\left(\beta_{6}\right)$ or the expected number of points $\left(\beta_{7}\right)$. The goals ahead parameter estimate is significant and positive for six of the clubs, and for the pooled sample, while the surprise points at home parameter is positive and significant for five of the clubs, and for the pooled sample. This indicates that, for some clubs, when interpreting the value relevance of match results, the market evaluates the margin of a win or loss rather than merely the outcome. Also, unexpectedly winning points at home is more highly prized by investors than would be the case for a comparable win away. The finding that points surprises have a larger effect for home games may be explained by the sentimental attachment of fans to particular clubs leading to a willingness to place a wager on their club to win with little regard to the odds offered. Supporters might be more likely to bet on the results of home games (for example, as part of the ritual of attending the match) than on away games. If the odds setters are aware of this phenomenon, they will tend to bias the odds against the home team to reflect the likely weight of money. In consequence, the points surprises for home games, measured using the odds, are reduced in size. Therefore the $S_{t} H_{t}$ variable has a positive and statistically significant effect on share returns as it accounts for the sentimental bias in the odds for home games.

Table 6 presents the results from estimating the additive formulation given by equation (11) and also including the variables that are a priori expected to be irrelevant in determining stock returns. ${ }^{9}$ It is clear that, when considered separately in an additive model, the point surprise and proximity to the end of the season have some role to play in determining stock returns, but the extent to which the clubs in the match are close rivals does not. The coefficients on the surprise points and time of the season variables are significant and positive for two and three of the clubs respectively, in each case, and in the

\footnotetext{
${ }^{9}$ To avoid repetition, the restricted versions of this model are not separately tabulated.
} 
pooled regression, whereas the rivalry coefficients are only significant and positive for one of the clubs and not significant in the pooled specification. However, rivalry has more of a role to play when it is interacted with the goal surprise variable (significantly negative for five clubs, and in the pooled regression) than when it is used on its own. The coefficient on the goals ahead variable is significantly positive for two clubs and the pooled sample. The surprise points at home variable is the only other one that is significant for the pooled sample.

In Table 4, the goal surprise variable (weighted by the rivalry score), for most clubs and for the pooled regression, does not have a significant effect on returns. However, in Tables 5 and 6 , it has a negative effect on returns when the number of goals ahead is also included, and the latter variable has a positive effect on returns. This finding may be the result of mean reversion (or negative serial correlation) in the expected number of goals benchmark - for example, where a few big wins are followed by a lower actual number of goals ahead (e.g. if a club has a run of easy matches followed by a clash with the table leader) so that the benchmark value is too high for this result and the goal surprise variable is too low. Similarly, several losses in a row followed by a higher actual number of goals ahead will lead the benchmark to be overstated and the goal surprise will be too high. If this is the case, it could be shown that when returns are regressed on both the goal surprise and the actual number of goals ahead, the parameter on the goal surprise variable will tend to be negative, while there will be a positive relationship between returns and the benchmark (as seen in Tables 5 and 6). However, when the goal surprise is used alone in the regression model (Table 4), the benchmark tends to be negatively correlated with returns, while the actual number of goals ahead is positively correlated with returns, leading to an insignificant coefficient on the goals surprise variable.

It is interesting to consider whether the unexpected portion of a club's result has a larger effect on the stock prices of large, liquid clubs such as Manchester United, Chelsea, or Tottenham Hotspur, or for smaller clubs with infrequently traded shares, and it is possible to argue intuitively in either direction. It may be the case that smaller clubs have bigger reactions to unexpected results as a result of the paucity of other relevant news and information about the companies. On the other hand, the shares of larger clubs may be held by proportionately fewer fans and more by conventional investors. The latter are more likely to be willing to sell their shares (buy shares) in the face of a run of bad (good) results if they feel that this augurs poorly (well) for the future profitability of the club. Although our results are mixed on this issue, it appears that the share prices of larger clubs are slightly less affected than those of smaller clubs by what happens on the pitch.

Finally, Table 7 considers whether the markets react slowly to match results by regressing stock returns two trading days after a match (as opposed to one day after a match in all our previous analysis) on the 
variables in equation (6). Thus the results of estimating equation (10) in Table 7 can be directly compared with those of Table 4. It is clear that, despite the infrequent trading, lack of liquidity and high transactions costs, there is only modest evidence that the information contained in match results continues to impact stock returns on the second trading day after the game. Interestingly, however, the coefficient on the lagged points variable is still highly significant for the overall sample, perhaps reflecting the impact of the large sample size on the standard errors.

\section{Conclusions}

This study has examined the impact of league point surprises and goal surprises on the prices of quoted English football clubs, using two new measures of the importance of the game. The results for the pooled sample show reasonably clear results, while those for individual clubs reveal more variety. Our main finding is that, while match results affect the share price, these effects are modest compared with the changes in club stock prices caused by other variables. As a result, the proportion of the variation in share prices explained by match results is very small. The market index mostly has a significant positive effect on returns, as the CAPM predicts, although for every $1 \%$ rise in the index, the share price rises by only about $0.1 \%$. As expected, points surprises and lagged points surprises have a positive influence on returns. The illiquidity and transactions costs may be partly responsible for the lagged response to points surprises, although the size of the lagged response is much smaller than the initial response. Points surprises from home games have an additional positive effect. The importance of the game, when measured either in terms of the degree of rivalry between the two match competitors, or in terms of the closeness of the match to the end of the season, appear to have a very modest impact on returns. Goal surprises and lagged goal surprises do not have a positive effect on returns. However, the goals ahead variable does have a positive effect, particularly for home games. In accordance with efficient markets, expected points have no effect, and it is unexpected points that have the effect.

In summary, our findings suggest that financial markets do react to match results when pricing football stocks, but in a fairly crude fashion. The finding that unexpected football results affect share returns over the closed market period supports the view that football results are price sensitive information and that there is no evidence against the notion that the stock market is semi-strong form efficient. It is possible that a more refined measure of importance based on a consideration of each game individually may yield stronger results, and this is an obvious, although labour-intensive, suggestion for further research. In addition, the fact that we have only considered the average short run impacts of individual matches is a possible limitation of the work.

An additional interesting question that subsequent research may consider would be the reverse of our line of causality - that is, how much do financial fortunes affect on-field performance? There is 
evidence for clubs that a key determinant of performance is the wage bill, so if a club has more money it can recruit more expensive players (for example, Chelsea and Manchester City). But are lower stock market valuations reflected in lower club spending, and if so what is the size of the performance impact? While a firm's share price has no direct effect on the operations of the company, the issue is the extent to which a low share price adversely affects a firm's ability to raise new finance on good terms. Intuition does not provide a definitive answer to this question, and it is therefore worthy of empirical investigation.

\section{References}

Amir, E. and Livne, G. (2005) Accounting, Valuation and Duration of Football Player Contracts, Journal of Business Finance and Accounting, vol. 32, nos. 3\&4, pp. 549-586.

Ashton, J.K., Gerrard, B. and Hudson, R. (2003) Economic Impact of National Sporting Success: Evidence from the London Stock Exchange, Applied Economics Letters, vol. 10, no. 12, pp. 783-785.

Audas, R., Dobson, S. and Goddard, J. (2002) The Impact of Managerial Change on Team Performance in Professional Sports, Journal of Economics and Business, vol. 54, no. 6, pp. 633-650.

Barajas, A., Fernandez-Jardon, C. and Crolley, L. (2007) Does Sports Performance Influence Revenues and Economic Results in Spanish Football? Working paper, University of Vigo.

Baur, D.G. and McKeating, C. (2009) The Benefits of Financial Markets: a Case Study of European Football Clubs, Working paper, Dublin City University.

Benkraiem, R., Le Roy, F. and Louchichi, W. (2010) Sporting Performances and the Volatility of Listed English Football Clubs, Paper presented to the European Financial Management Association 2010 meeting in Aarhus.

Benkraiem, R., Louchichi, W. and Marques, P. (2009) Market Reaction to Sporting Results: The Case of European Listed Football Clubs, Management Decision, vol. 47, no. 1, pp. 100-109.

Bernile, G. and Lyandres, E. (2008) Understanding Investor Sentiment: The Case of Soccer, Working paper, University of Miami.

Berument, H., Ceylan, N.B. and Gozpinar, E. (2006) Performance of Soccer on the Stock Market: Evidence from Turkey, Social Sciences Journal, vol. 43, no. 4, pp. 695-699.

Berument, H. and Yucel, E.M. (2005) Long Live Fenerbahce: The Production Boosting Effects of Football, Journal of Economic Psychology, vol. 26, no. 6, pp. 842-861.

Braun, S. and Kvasnicka, M. (2008) Against All Odds? National Sentiment and Wagering on European Football, Working paper, no. 42, University of Bochum.

Brown, G.W. and Hartzell, J.C. (2001) Market Reaction to Public Information - The Atypical Case of the Boston Celtics, Journal of Financial Economics, vol. 60, no. 2-3, pp. 333-370.

Bruinshoofd, A. and Ter Weel, B. (2003) Manager To Go? Performance Dips Reconsidered With Evidence From Dutch Football, European Journal of Operational Research, vol. 148, no. 2, pp. 233-246.

Cain, M., Law, D. and Peel, D. (2000) The Favourite Longshot Bias and Market Efficiency in UK Football Betting, Scottish Journal of Political Economy, vol. 47, no. 1., pp. 25-36.

Carroll, D., Ebrahim, S., Tilling, K., Macleod, J. and Davey Smith, G. (2002) Admissions for Myocardial Infarction and World Cup Football: Database Survey, British Medical Journal, vol. 325 , no. 7378,21 , pp. 1439-1442.

Deschamps, B. and Gergaud, O. (2007) Efficiency in Betting Markets: Evidence from English Football, Journal of Prediction Markets, vol. 1, no. 1, pp. 61-73.

Dios Tena, J.D. and Forrest, D. (2007) Within-Season Dismissal of Football Coaches: Statistical Analysis of Causes and Consequences, European Journal of Operational Research, vol. 181, no. 1, pp. 362-373. 
Dixon, M.J. and Pope, P.F. (2004) The Value of Statistical Forecasts in the UK Association Football Betting Market, International Journal of Forecasting, vol. 20, no. 4, pp. 697-711.

Dobson, S. and Goddard, J. (2001) The Economics of Football, Cambridge University Press.

Dohmen, T.J., Falk, A., Huffman, D. and Sunde, U. (2006) Seemingly Irrelevant Events Affect Economic Perceptions and Expectations: The FIFA World Cup 2006 as a Natural Experiment, Discussion Paper no. 2275, Institute for the Study of Labour, University of Bonn.

Duque, J. and Ferreira, N.A. (2008) Explaining Share Price Performance of Football Clubs Listed on the Euronext Lisbon, Working Paper, Technical University of Lisbon.

Edmans, A. Garcia, D. and Norli, O. (2007) Sports Sentiment and Stock Returns, Journal of Finance, vol. 62, 4, pp. 1967-1998.

Forrest, D. (2008) Soccer Betting in Britain. In Handbook of Sports and Lottery Markets, edited by D.B. Hausch and W.T. Ziemba, Elsevier, pp. 421-446.

Forrest, D., Goddard, J. and Simmons, R. (2005) Odds Setters as Forecasters: The Case of English Football, International Journal of Forecasting, vol. 21, no. 3, pp. 551-564.

Forrest, D. and Simmons, R. (2005) Efficiency of the Odds on English Professional Football Matches. In Information Efficiency in Financial and Betting Markets, edited by L. Vaughan Williams, Cambridge University Press, pp. 330-338.

Forrest, D. and Simmons, R. (2008) Sentiment in the Betting Market on Spanish Football, Applied Economics, vol. 40, no. 1, pp. 119-126.

Fotaki, M., Markellos, R.N. and Mania, M. (2009) Human Resources Turnover as an Asset Acquisition, Accumulation and Divestiture Process, Working paper, Athens University of Economics and Business.

Franck, E., Verbeek, E. and Nuesch, S. (2008) The Sentiment Bias in English Soccer Betting, Working paper, University of Zurich, No. 69.

Frick, B. and Simmons, R. (2008) The Impact of Managerial Quality on Organizational Performance: Evidence from German Soccer, Managerial and Decision Economics, vol. 29, no. 7, pp. 593 600.

Gannon, J., Evans, K. and Goddard, J. (2006) The Stock Market Effects of the Sale of Live Broadcasting Rights for English Premiership Football, Journal of Sports Economics, vol. 7, no. 2, May, pp. 168-186.

Goddard, J. and Asimakopoulos, I. (2004) Forecasting Football Results and the Efficiency of Fixed Odds Betting, Journal of Forecasting, vol. 23, no. 1, pp. 51-66.

Graham, I. and Stott, H. (2008) Predicting Bookmaker Odds and Efficiency for UK Football, Applied Economics, vol. 40, no. 1, pp. 99-109.

Jones, D. (ed) (2009) Deloitte Football Money League: Lost in Translation, vol. 12, Sports Business Group at Deloitte

Kaplanski, G. and Levy, H. (2010) Exploitable Predictable Irrationality: The FIFA World Cup Effect on the US Stock Market, Journal of Financial and Quantitative Analysis, vol. 45, no. 2, pp. 535553.

Kirkup, W. and Merrick, D.W. (2003) A Matter of Life and Death: Population Mortality and Football Results, Journal of Epidemiology and Community Health, vol. 57, no. 6, pp. 429-432.

Koning, R.H. (2003) An Econometric Evaluation of the Effect of Firing a Coach on Team Performance, Applied Economics, vol. 35, no. 5, pp. 555-564.

Kuypers, T. (2000) Information and Efficiency: An Empirical Study of a Fixed Odds Betting Market, Applied Economics, vol. 32, no. 11, pp. 1353-1363.

Makropoulou, V.A. and Markellos, R.N. (2007) Optimal Price Setting in Fixed-Odds Betting Markets Under Information Uncertainty, Working paper, Athens University of Economics and Business, February.

Morrow, S. (1999) The New Business of Football: Accountability and Finance in Football, Palgrave, pp. 93-97.

Palomino, F., Renneboog, L. and Zhang, C. (2005) Stock Price Reactions to Short-Lived Public Information: The Case of Betting Odds, TILEC Discussion Paper, DP 2005-016, Tilburg University. 
Palomino, F., Renneboog, L. and Zhang, C. (2009) Information Salience, Investor Sentiment and Stock Returns: The Case of British Soccer Betting, Journal of Corporate Finance, vol. 15, no. 3, pp. 368-387.

Pinnuck, M. and Potter, B. (2006) Impact of On-Field Football Success on the Off-Field Financial Performance of AFL Football Clubs, Accounting and Finance, vol. 46, no. 3, pp. 499-517.

Pujol, F. (2008) A Cyclical Learning Process Under Uncertainty: The Spanish Soccer Betting Game Evidence, Working paper, University of Navarre.

Renneboog, L. and Vanbrabant, P. (2000) Share Price Reactions to Sporty Performances of Soccer Clubs Listed on the London Stock Exchange and the AIM, Working Paper, Tilburg University.

Scholtens, B. and Peenstra, W. (2009) Scoring on the Stock Exchange? The Effect of Football Matches on Stock Market Returns: An Event Study, Applied Economics, vol. 41, no. 25, pp. 3231-3237.

Scherr, F., Abbott, A. and Thompson, M. (1993) Returns When Signals of Value are Frequent: The Boston Celtics, Journal of Business and Economic Studies, vol. 2, no. 1, pp. 69-83.

Sharpe, G. (1997) Gambling on Goals: A Century of Football Betting, Mainstream Publishing, Edinburgh.

Spais, G.S. and Filis, G.N. (2008) Measuring Stock Market Reaction to Sponsorship Announcements The Case of Fiat and Juventus, Journal of Targeting, Measurement and Analysis for Marketing, vol. 16, no. 3, pp. 169-180.

Spann, M. and Skiera, B. (2009) Sports Forecasting: A Comparison of the Forecast Accuracy of Prediction Markets, Betting Odds and Tipsters, Journal of Forecasting, vol. 28, no. 1, pp. 5572.

Stadtmann, G. (2006) Frequent News and Pure Signals: The Case of a Publicly Traded Football Club, Scottish Journal of Political Economy, vol. 53, no. 4 pp. 485-504.

Szymanski, S. and Kuypers, T. (1999) Winners and Losers: The Business Strategy of Football, Penguin.

Ter Weel, B. (2006) Does Manager Turnover Improve Firm Performance? New Evidence Using Information from Dutch Soccer, 1986-2004, Working paper, University of Maastricht.

Tufan, E. (2006) Do World Cup Football Matches Affect Istanbul Stock Exchange? The ICFAI University Journal of Behavioral Finance.

Vlastakis, N., Dotsis, G. and Markellos, R.N. (2009) How Efficient is the European Betting Market? Evidence from Arbitrage and Trading Strategies, Journal of Forecasting vol. 28, no. 5, pp. 426444.

Wilbert-Lampen, U., Leistner, D., Greven, S., Pohl, T., Sper, S., Volker, C., Guthlin, D., Plasse, A., Knez, A., Kuchenhoff, H. and Steinbeck, G. (2008) Cardiovascular Events During World Cup Soccer, New England Journal of Medicine, vol. 358, no. 5, 31 pp. 475-483.

Witte, D.R., Bots, M.L., Hoes, A.W. and Grobbee, D.E. (2000) Cardiovascular Mortality in Dutch Men During 1996 European Football Championship: Longitudinal Population Study, British Medical Journal, vol. 321, no. 7276, 23, pp. 1552-1554.

Zuber, R.A., Yiu, P., Lamb, R.P. and Gandar, J.M. (2005) Investor-Fans? An Examination of the Performance of Publicly Traded English Premier League Teams, Applied Financial Economics, vol. 15 , no. 5 , pp. $305-313$. 
Table 1: Data Periods for the Sample of Football Clubs

\begin{tabular}{|c|c|c|}
\hline Club & First used in sample & Ceases to be quoted \\
\hline Aston Villa & Start 00/01 season & $17^{\text {th }}$ October 2006 \\
\hline Birmingham & Start $00 / 01$ season & End $07 / 08$ season \\
\hline Bolton Wanderers & Start $00 / 01$ season & $1^{\text {st }}$ May 2003 \\
\hline Charlton Athletic & Start $00 / 01$ season & $21^{\text {st }}$ September 2006 \\
\hline Chelsea & Start $00 / 01$ season & $26^{\text {th }}$ August 2003 \\
\hline Leeds United & Start $00 / 01$ season & $28^{\text {th }}$ April 2004 \\
\hline Leicester City & Start $00 / 01$ season & $25^{\text {th }}$ November 2002 \\
\hline Manchester United & Start $00 / 01$ season & $22^{\text {nd }}$ June 2005 \\
\hline Millwall & Start $00 / 01$ season & End $07 / 08$ season \\
\hline Newcastle United & Start $00 / 01$ season & $18^{\text {th }}$ July 2007 \\
\hline Nottingham Forest & Start $00 / 01$ season & $16^{\text {th }}$ April 2002 \\
\hline Preston North End & Start $00 / 01$ season & End $07 / 08$ season \\
\hline Queens Park Rangers & Start $00 / 01$ season & $2^{\text {nd }}$ April 2001 \\
\hline Sheffield United & Start $00 / 01$ season & End $07 / 08$ season \\
\hline Southampton & Start $00 / 01$ season & End $07 / 08$ season \\
\hline Sunderland & Start $00 / 01$ season & $5^{\text {th }}$ August 2004 \\
\hline Tottenham Hotspur & Start $00 / 01$ season & End $07 / 08$ season \\
\hline West Bromwich Albion & Start $00 / 01$ season & $11^{\text {th }}$ January 2005 \\
\hline Watford & $1^{\text {st }}$ August 2001 & End $07 / 08$ season \\
\hline
\end{tabular}

Table 2: Average of the Actual Odds and of the Expected Odds

\begin{tabular}{lccc}
\hline & Odds & Actual Results & Difference \\
\hline Home Win & 0.446 & 0.458 & -0.012 \\
Away Win & 0.284 & 0.273 & 0.011 \\
Draw & 0.270 & 0.270 & 0.000 \\
\hline
\end{tabular}


Table 3: Summary statistics for football stocks

\begin{tabular}{lrrrrrr}
\hline Team & $\begin{array}{r}\text { Market cap } \\
(£ \text { millions })\end{array}$ & $\begin{array}{r}\text { \% of days } \\
\text { with no } \\
\text { trading }\end{array}$ & $\begin{array}{r}\text { Number of } \\
\text { days for which } \\
\text { we have data }\end{array}$ & $\begin{array}{r}\text { Number of days } \\
\text { with trading for } \\
\text { which we have data }\end{array}$ & $\begin{array}{r}\text { Value of } \\
\text { daily } \\
\text { volume }(£)\end{array}$ & $\begin{array}{r}\text { Spread as a } \% \\
\text { of Mid-Price }\end{array}$ \\
\hline Aston Villa & 30.23 & 30 & 1640 & 1153 & 12760 & 3.9 \\
Birmingham & 17.01 & 21 & 2134 & 1687 & 12869 & 13.2 \\
Bolton & 8.96 & 23 & 737 & 565 & 5259 & 16.1 \\
Charlton & 15.71 & 42 & 1622 & 936 & 2710 & 8.4 \\
Chelsea & 52.19 & 17 & 819 & 682 & 19925 & 7.3 \\
QPR & 5.24 & 2 & 194 & 190 & 1761 & 17.7 \\
Leeds & 29.92 & 11 & 954 & 851 & 68406 & 6.5 \\
Leicester & 13.25 & 23 & 592 & 454 & 14124 & 8.4 \\
Man United & 516.47 & 9 & 1296 & 1180 & 1548997 & 1.7 \\
Millwall & 9.78 & 7 & 2134 & 1986 & 19584 & 19.0 \\
Newcastle & 58.42 & 8 & 1835 & 1681 & 65260 & 4.7 \\
Nottingham Forest & 6.10 & 28 & 369 & 266 & 1606 & 14.0 \\
Preston & 5.05 & 67 & 2134 & 696 & 1170 & 5.7 \\
Sheffield United & 16.02 & 16 & 2134 & 1784 & 6226 & 14.4 \\
Southampton & 11.71 & 25 & 2134 & 1598 & 8681 & 6.8 \\
Sunderland & 19.45 & 46 & 1067 & 575 & 5748 & 4.0 \\
Tottenham Hotspur & 53.71 & 8 & 2134 & 1973 & 48178 & 6.3 \\
West Brom. Albion & 9.13 & 55 & 1179 & 533 & 3803 & 27.0 \\
Watford & 11.00 & 61 & 1852 & 720 & 2010 & 32.2 \\
\hline
\end{tabular}

Note: Entries are the averages for each club over the sample period for which we have data for a particular team; the non-trading days include public holidays; market cap is measured as an average over the days for which we have data. 
Table 4: Results for the model incorporating the effect of surprise results, strength rivalry with opposing team, proximity to end of season, and the surprise in goal difference on stock returns

Model: $R_{t}=\alpha+\beta_{1} M_{t}+\beta_{2}\left(S_{t} F_{t} R V_{t}\right)+\beta_{3}\left(G S_{t} R V_{t}\right)+\varepsilon_{t}$

\begin{tabular}{|c|c|c|c|c|}
\hline Team & $\alpha$ & $\beta_{1}$ & $\beta_{2}$ & $\beta_{3}$ \\
\hline \multirow[t]{2}{*}{ Aston Villa } & 0.043 & 0.108 & -0.003 & 0.0004 \\
\hline & $(0.038)$ & $(0.037) * * *$ & $(0.005)$ & $(0.003)$ \\
\hline \multirow[t]{2}{*}{ Birmingham } & 0.042 & 0.150 & 0.040 & 0.003 \\
\hline & $(0.060)$ & $(0.058) * * *$ & $(0.007)^{* * *}$ & $(0.003)$ \\
\hline \multirow[t]{2}{*}{ Bolton } & -0.139 & 0.396 & 0.044 & -0.001 \\
\hline & $(0.179)$ & $(0.138) * * *$ & $(0.015)^{* * *}$ & $(0.007)$ \\
\hline \multirow[t]{2}{*}{ Charlton } & -0.006 & -0.009 & 0.010 & 0.002 \\
\hline & $(0.044)$ & $(0.051)$ & $(0.010)$ & $(0.003)$ \\
\hline \multirow[t]{2}{*}{ Chelsea } & 0.040 & 0.301 & 0.016 & 0.002 \\
\hline & $(0.143)$ & $(0.129) * *$ & $(0.014)$ & $(0.007)$ \\
\hline \multirow[t]{2}{*}{ QPR } & -0.029 & 0.565 & 0.038 & -0.046 \\
\hline & $(0.244)$ & $(0.469)$ & $(0.011)$ & $(0.025)^{*}$ \\
\hline \multirow[t]{2}{*}{ Leeds } & -0.141 & 0.164 & 0.041 & 0.015 \\
\hline & $(0.156)$ & $(0.096) * *$ & $(0.015)^{* * *}$ & $(0.010)$ \\
\hline \multirow[t]{2}{*}{ Leicester } & -0.164 & -0.017 & 0.023 & -0.006 \\
\hline & $(0.159)$ & $(0.206)$ & $(0.012)^{* *}$ & $(0.007)$ \\
\hline \multirow[t]{2}{*}{ Man United } & 0.084 & 0.261 & 0.002 & 0.004 \\
\hline & $(0.078)$ & $(0.069) * * *$ & $(0.004)$ & $(0.004)$ \\
\hline \multirow[t]{2}{*}{ Millwall } & -0.118 & 0.086 & 0.037 & 0.005 \\
\hline & $(0.081)$ & $(0.067)$ & $(0.009)^{* * *}$ & $(0.003)$ \\
\hline \multirow[t]{2}{*}{ Newcastle } & 0.084 & 0.079 & 0.037 & -0.0007 \\
\hline & $(0.057)$ & $(0.063)$ & $(0.012)^{* * *}$ & $(0.004)$ \\
\hline \multirow[t]{2}{*}{ Nottingham Forest } & 0.046 & -0.068 & 0.093 & -0.008 \\
\hline & $(0.169)$ & $(0.120)$ & $(0.040)^{* *}$ & (0.009) \\
\hline \multirow[t]{2}{*}{ Preston } & -0.030 & 0.002 & 0.005 & -0.0006 \\
\hline & $(0.017)^{*}$ & $(0.013)$ & $(0.002)^{* *}$ & $(0.0009)$ \\
\hline \multirow[t]{2}{*}{ Sheffield United } & 0.017 & 0.138 & 0.045 & -0.007 \\
\hline & $(0.060)$ & $(0.055)^{* * *}$ & $(0.012)^{* * *}$ & $(0.005)$ \\
\hline \multirow[t]{2}{*}{ Southampton } & 0.001 & 0.018 & 0.026 & -0.006 \\
\hline & $(0.038)$ & $(0.035)$ & $(0.010)^{* * *}$ & $(0.003) * * *$ \\
\hline \multirow[t]{2}{*}{ Sunderland } & -0.053 & 0.023 & 0.033 & -0.009 \\
\hline & $(0.076)$ & $(0.062)$ & $(0.010)^{* * *}$ & $(0.003) * * *$ \\
\hline \multirow[t]{2}{*}{ Tottenham Hotspur } & 0.043 & 0.044 & 0.008 & 0.001 \\
\hline & $(0.035)$ & $(0.032)$ & $(0.006)$ & $(0.003)$ \\
\hline \multirow[t]{2}{*}{ West Brom. Albion } & 0.012 & -0.002 & 0.003 & -0.004 \\
\hline & $(0.026)$ & $(0.021)$ & $(0.002)^{*}$ & $(0.001) * * *$ \\
\hline \multirow[t]{2}{*}{ Watford } & -0.096 & -0.059 & 0.002 & 0.007 \\
\hline & $(0.079)$ & $(0.045)$ & $(0.006)$ & $(0.005)$ \\
\hline \multirow[t]{2}{*}{ All teams pooled } & -0.022 & 0.093 & 0.024 & 0.00007 \\
\hline & $(0.016)$ & $(0.016) * * *$ & $(0.002) * * *$ & $(0.001)$ \\
\hline
\end{tabular}

Notes: Cell entries are parameter estimates with heteroscedasticity and autocorrelation-consistent standard errors in parentheses; * ** and *** denote significance at the $10 \%, 5 \%$ and $1 \%$ levels respectively. 
Table 5: Results for the model incorporating the effect of surprise results and the surprise in goal difference on football stock returns

Model: $R_{t}=\alpha+\beta_{1} M_{t}+\beta_{2}\left(S_{t} F_{t} R V_{t}\right)+\beta_{3}\left(G S_{t} R V_{t}\right)+\beta_{4} G A_{t}+\beta_{5} S_{t} H_{t}+\beta_{6} G S_{t} H_{t}+\beta_{7} E P_{t}+\varepsilon_{t}$

\begin{tabular}{|c|c|c|c|c|c|c|c|c|}
\hline Team & $\alpha$ & $\beta_{1}$ & $\beta_{2}$ & $\beta_{3}$ & $\beta_{4}$ & $\beta_{5}$ & $\beta_{6}$ & $\beta_{7}$ \\
\hline \multirow[t]{2}{*}{ Aston Villa } & 0.027 & 0.103 & 0.003 & -0.00006 & -0.102 & -0.439 & 0.433 & 0.029 \\
\hline & $(0.039)$ & $(0.036) * * *$ & $(0.007)$ & (0.004) & $(0.098)$ & $(0.371)$ & $(0.291)$ & $(0.078)$ \\
\hline \multirow[t]{2}{*}{ Birmingham } & 0.074 & 0.151 & 0.028 & 0.004 & 0.178 & 0.489 & -0.771 & -0.148 \\
\hline & $(0.062)$ & $(0.058) * * *$ & $(0.009) * * *$ & $(0.003)$ & $(0.151)$ & $(0.264)^{*}$ & $(0.370)^{* *}$ & $(0.140)$ \\
\hline \multirow[t]{2}{*}{ Bolton } & -0.253 & 0.385 & 0.014 & -0.006 & 0.386 & 0.879 & 0.317 & 0.568 \\
\hline & (0.197) & $(0.137)^{* *}$ & $(0.016)$ & $(0.007)$ & $(0.354)^{*}$ & $(0.487)^{* *}$ & (0.384) & $(0.359)$ \\
\hline \multirow[t]{2}{*}{ Charlton } & 0.020 & -0.005 & 0.003 & -0.0005 & 0.116 & -0.083 & 0.086 & -0.065 \\
\hline & $(0.046)$ & $(0.051)$ & $(0.012)$ & $(0.003)$ & $(0.134)$ & $(0.211)$ & $(0.171)$ & $(0.134)$ \\
\hline \multirow[t]{2}{*}{ Chelsea } & 0.088 & 0.301 & 0.010 & 0.004 & 0.003 & 0.520 & -0.241 & -0.099 \\
\hline & $(0.163)$ & $(0.130) * *$ & $(0.019)$ & $(0.008)$ & $(0.439)$ & $(0.727)$ & $(0.461)$ & $(0.214)$ \\
\hline \multirow[t]{2}{*}{ QPR } & 0.493 & 0.562 & 0.002 & -0.088 & 1.203 & -0.604 & -0.028 & -0.370 \\
\hline & $(0.358)$ & $(0.461)$ & $(0.012)$ & $(0.040) * *$ & $(0.543) * *$ & $(0.806)$ & $(0.613)$ & $(0.369)$ \\
\hline \multirow[t]{2}{*}{ Leeds } & -0.206 & 0.139 & 0.022 & 0.008 & 0.412 & -0.397 & 0.657 & 0.112 \\
\hline & $(0.164)$ & (0.099) & $(0.017)$ & (0.010) & $(0.445)$ & $(0.683)$ & $(0.483)$ & $(0.253)$ \\
\hline \multirow[t]{2}{*}{ Leicester } & -0.081 & -0.002 & 0.033 & -0.009 & 0.398 & -0.888 & 0.007 & -0.158 \\
\hline & $(0.182)$ & $(0.207)$ & $(0.016) * *$ & $(0.007)$ & $(0.319)$ & $(0.436)^{* *}$ & $(0.342)$ & $(0.291)$ \\
\hline \multirow[t]{2}{*}{ Man United } & 0.018 & 0.259 & -0.005 & 0.0009 & 0.318 & -0.195 & 0.130 & -0.104 \\
\hline & $(0.088)$ & $(0.068) * * *$ & $(0.005)$ & (0.004) & $(0.158)^{* *}$ & $(0.275)$ & $(0.187)$ & $(0.113)$ \\
\hline \multirow[t]{2}{*}{ Millwall } & -0.146 & 0.081 & 0.025 & -0.002 & 0.482 & 0.226 & 0.013 & -0.024 \\
\hline & $(0.083)^{*}$ & (0.067) & $(0.011)^{* *}$ & (0.004) & $(0.230)^{* *}$ & $(0.348)$ & $(0.260)$ & $(0.155)$ \\
\hline \multirow[t]{2}{*}{ Newcastle } & 0.043 & 0.077 & 0.046 & -0.005 & -0.008 & -0.046 & 0.218 & 0.134 \\
\hline & $(0.059)$ & $(0.063)$ & $(0.015)^{* * *}$ & (0.004) & $(0.156)$ & $(0.351)$ & $(0.385)$ & $(0.111)$ \\
\hline Nottingham & 0.217 & -0.077 & 0.048 & 0.001 & -0.034 & 2.300 & -1.218 & -0.690 \\
\hline Forest & $(0.169)$ & $(0.123)$ & $(0.027)^{*}$ & $(0.011)$ & $(0.280)$ & (1.815) & (1.029) & $(0.442)$ \\
\hline \multirow[t]{2}{*}{ Preston } & -0.045 & -0.0003 & 0.003 & -0.002 & 0.069 & 0.001 & -0.009 & 0.054 \\
\hline & $(0.019) * *$ & $(0.013)$ & $(0.002)$ & $(0.001)$ & $(0.032)^{* *}$ & $(0.063)$ & $(0.024)$ & $(0.024)^{* *}$ \\
\hline Sheffield & 0.016 & 0.146 & 0.024 & -0.017 & 0.535 & 0.880 & -0.213 & -0.098 \\
\hline United & $(0.058)$ & $(0.055) * * *$ & $(0.015)$ & $(0.005)^{* * *}$ & $(0.242)^{* *}$ & $(0.465)^{*}$ & $(0.348)$ & $(0.153)$ \\
\hline \multirow[t]{2}{*}{ Southampton } & 0.025 & 0.020 & 0.020 & -0.008 & 0.146 & 0.090 & -0.053 & -0.094 \\
\hline & $(0.041)$ & $(0.035)$ & $(0.013)$ & $(0.003) * * *$ & $(0.108)$ & (0.199) & $(0.129)$ & $(0.075)$ \\
\hline \multirow[t]{2}{*}{ Sunderland } & -0.049 & 0.025 & 0.036 & -0.010 & 0.021 & -0.335 & 0.091 & -0.019 \\
\hline & $(0.086)$ & $(0.063)$ & $(0.012)^{* *}$ & $(0.004) * *$ & $(0.141)$ & $(0.315)$ & $(0.289)$ & $(0.121)$ \\
\hline Tottenham & 0.035 & 0.043 & 0.002 & 0.001 & 0.062 & 0.347 & -0.221 & 0.066 \\
\hline Hotspur & (0.037) & $(0.032)$ & (0.006) & (0.003) & $(0.126)$ & $(0.178)^{*}$ & (0.154) & $(0.070)$ \\
\hline West Brom. & 0.002 & -0.003 & 0.004 & -0.004 & -0.043 & -0.037 & -0.106 & 0.043 \\
\hline Albion & $(0.029)$ & $(0.021)$ & $(0.002)^{*}$ & $(0.001) * * *$ & $(0.033)$ & $(0.058)$ & $(0.085)$ & $(0.034)$ \\
\hline \multirow[t]{2}{*}{ Watford } & 0.001 & -0.057 & 0.003 & 0.003 & 0.294 & -0.107 & 0.002 & -0.365 \\
\hline & $(0.079)$ & $(0.046)$ & $(0.005)$ & $(0.005)$ & $(0.215)$ & $(0.315)$ & $(0.272)$ & $(0.170)^{* *}$ \\
\hline All teams & -0.019 & 0.093 & 0.016 & -0.002 & 0.184 & 0.163 & -0.003 & -0.025 \\
\hline pooled & $(0.017)$ & $(0.016) * * *$ & $(0.003) * * *$ & $(0.001) * *$ & $(0.045)^{* * *}$ & $(0.081) * *$ & $(0.064)$ & $(0.034)$ \\
\hline
\end{tabular}

Notes: Cell entries are parameter estimates with heteroscedasticity and autocorrelation-consistent standard errors in parentheses; $*$, ** and $* * *$ denote significance at the $10 \%, 5 \%$ and $1 \%$ levels respectively. 
Table 6: Results for the additive model incorporating the effect of match variables on football stock returns

Model:

$$
R_{t}=\alpha+\beta_{1} M_{t}+\beta_{2} S_{t}+\beta_{3} F_{t} D_{t}+\beta_{4} R V_{t} D_{t}+\beta_{5} G S_{t} R V_{t}+\beta_{6} G A_{t}+\beta_{7} S_{t} H_{t}+\beta_{8} G S_{t} H_{t}+\beta_{9} E P_{t}+\varepsilon_{t}
$$

\begin{tabular}{|c|c|c|c|c|c|c|c|c|c|c|}
\hline Team & $\alpha$ & $\beta_{1}$ & $\beta_{2}$ & $\beta_{3}$ & $\beta_{4}$ & $\beta_{5}$ & $\beta_{6}$ & $\beta_{7}$ & $\beta_{8}$ & $\beta_{9}$ \\
\hline \multirow[t]{2}{*}{ Aston Villa } & 0.028 & 0.103 & 0.436 & -0.248 & -0.045 & 0.0002 & -0.177 & -0.518 & 0.484 & 0.250 \\
\hline & $(0.039)$ & $(0.036)^{* * *}$ & $(0.392)$ & $(0.233)$ & $(0.040)$ & $(0.004)$ & $(0.150)$ & $(0.448)$ & $(0.324)$ & $(0.211)$ \\
\hline \multirow[t]{2}{*}{ Birmingham } & 0.078 & 0.148 & 0.009 & 0.386 & -0.006 & 0.004 & 0.344 & 0.672 & -0.717 & -0.316 \\
\hline & $(0.063)$ & $(0.058) * *$ & $(0.386)$ & $(0.326)$ & $(0.046)$ & $(0.003)$ & $(0.179)$ & $(0.309)^{* *}$ & $(0.364)^{* *}$ & $(0.239)$ \\
\hline \multirow[t]{2}{*}{ Bolton } & -0.249 & 0.393 & 0.511 & 0.040 & -0.063 & -0.006 & 0.401 & 0.923 & 0.331 & 0.791 \\
\hline & $(0.197)$ & $(0.137)^{* * *}$ & (0.967) & $(0.353)$ & $(0.098)$ & $(0.007)$ & $(0.428)$ & $(0.728)$ & $(0.406)$ & $(0.616)$ \\
\hline \multirow[t]{2}{*}{ Charlton } & 0.021 & -0.004 & -0.361 & -0.085 & 0.033 & -0.0004 & 0.224 & 0.116 & 0.021 & -0.171 \\
\hline & $(0.046)$ & $(0.051)$ & $(0.323)$ & $(0.214)$ & $(0.030)$ & $(0.003)$ & $(0.190)$ & $(0.322)$ & $(0.198)$ & $(0.185)$ \\
\hline \multirow[t]{2}{*}{ Chelsea } & 0.086 & 0.306 & -2.279 & 0.403 & 0.192 & 0.005 & 1.030 & 1.403 & -0.958 & -1.313 \\
\hline & $(0.164)$ & $(0.129)^{* *}$ & $(0.868)^{* * *}$ & $(0.395)$ & $(0.078) * *$ & $(0.008)$ & $(0.605)^{*}$ & $(0.785)^{*}$ & $(0.565)^{*}$ & $(0.391)^{* * *}$ \\
\hline \multirow[t]{2}{*}{ QPR } & 0.523 & 0.558 & 2.691 & -0.770 & -0.029 & -0.091 & 0.592 & -2.449 & 0.391 & -0.134 \\
\hline & $(0.354)$ & $(0.458)$ & $(1.510)^{*}$ & (1.053) & $(0.054)$ & $(0.040)^{* *}$ & $(0.628)$ & $(1.282)^{*}$ & $(0.633)$ & $(0.294)$ \\
\hline \multirow[t]{2}{*}{ Leeds } & -0.218 & 0.140 & 1.078 & -0.947 & 0.102 & 0.007 & 0.206 & -1.035 & 0.827 & 0.196 \\
\hline & $(0.164)$ & $(0.098)$ & $(0.850)$ & $(0.600)$ & $(0.109)$ & $(0.010)$ & $(0.575)$ & $(0.776)$ & $(0.490)^{*}$ & $(0.433)$ \\
\hline \multirow[t]{2}{*}{ Leicester } & -0.085 & -0.009 & 0.451 & -0.226 & 0.036 & -0.009 & 0.317 & -0.863 & 0.032 & 0.180 \\
\hline & $(0.182)$ & $(0.209)$ & $(0.690)$ & $(0.228)$ & (0.094) & $(0.008)$ & $(0.428)$ & $(0.503)^{*}$ & $(0.379)$ & $(0.526)$ \\
\hline \multirow[t]{2}{*}{ Man United } & 0.020 & 0.259 & 0.222 & 0.019 & -0.040 & 0.0009 & 0.190 & -0.346 & 0.211 & 0.049 \\
\hline & $(0.088)$ & $(0.068)^{* * *}$ & $(0.406)$ & $(0.182)$ & $(0.034)$ & $(0.004)$ & $(0.244)$ & $(0.360)$ & $(0.224)$ & $(0.206)$ \\
\hline \multirow[t]{2}{*}{ Millwall } & -0.156 & 0.083 & 0.858 & 0.189 & -0.026 & -0.002 & 0.301 & -0.051 & 0.137 & 0.104 \\
\hline & $(0.084)^{*}$ & $(0.067)$ & $(0.450)^{*}$ & $(0.264)$ & (0.034) & $(0.004)$ & $(0.296)$ & $(0.362)$ & $(0.278)$ & $(0.233)$ \\
\hline \multirow[t]{2}{*}{ Newcastle } & 0.052 & 0.079 & -0.769 & 1.299 & 0.062 & -0.002 & 0.235 & 0.338 & 0.109 & -0.474 \\
\hline & $(0.059)$ & $(0.062)$ & $(0.617)$ & $(0.422)^{* * *}$ & $(0.046)$ & $(0.004)$ & $(0.253)$ & $(0.530)$ & $(0.376)$ & $(0.221)^{* *}$ \\
\hline Nottingham & 0.212 & -0.065 & -0.710 & 1.957 & 0.106 & 0.002 & 0.189 & 2.713 & -1.571 & -1.515 \\
\hline Forest & $(0.169)$ & $(0.125)$ & $(1.025)$ & $(1.182)^{*}$ & $(0.156)$ & $(0.011)$ & $(0.414)$ & $(1.767)$ & $(1.025)$ & $(1.128)$ \\
\hline \multirow[t]{2}{*}{ Preston } & -0.045 & 0.00004 & 0.012 & 0.087 & -0.005 & -0.001 & 0.081 & 0.030 & -0.018 & 0.051 \\
\hline & $(0.019) * *$ & $(0.013)$ & $(0.078)$ & $(0.052)^{*}$ & $(0.006)$ & $(0.001)$ & $(0.043)^{*}$ & $(0.080)$ & $(0.028)$ & $(0.039)$ \\
\hline Sheffield & 0.021 & 0.146 & 0.711 & 0.599 & -0.067 & -0.015 & 0.437 & 0.902 & -0.207 & -0.023 \\
\hline United & $(0.057)$ & $(0.056)^{* * *}$ & $(0.447)$ & $(0.452)$ & $(0.042)$ & $(0.005)^{* * *}$ & $(0.297)$ & $(0.539)^{*}$ & $(0.377)$ & $(0.226)$ \\
\hline \multirow{2}{*}{ Southampton } & 0.023 & 0.024 & 0.113 & 0.028 & 0.036 & -0.008 & 0.130 & 0.007 & -0.014 & -0.253 \\
\hline & $(0.041)$ & $(0.035)$ & $(0.296)$ & $(0.295)$ & $(0.040)$ & $(0.003)^{* * *}$ & $(0.126)$ & $(0.237)$ & $(0.136)$ & $(0.168)$ \\
\hline \multirow[t]{2}{*}{ Sunderland } & -0.042 & 0.013 & -0.040 & 0.583 & -0.032 & -0.009 & 0.278 & 0.294 & -0.069 & -0.203 \\
\hline & $(0.087)$ & $(0.066)$ & $(0.499)$ & $(0.388)$ & $(0.070)$ & $(0.004)^{* *}$ & $(0.223)$ & $(0.510)$ & $(0.372)$ & $(0.267)$ \\
\hline Tottenham & 0.035 & 0.044 & 0.223 & -0.024 & -0.011 & 0.001 & -0.017 & 0.243 & -0.171 & 0.120 \\
\hline Hotspur & $(0.037)$ & $(0.033)$ & $(0.282)$ & $(0.170)$ & $(0.026)$ & $(0.003)$ & $(0.182)$ & $(0.255)$ & $(0.182)$ & $(0.122)$ \\
\hline West Brom. & 0.002 & -0.004 & -0.003 & 0.106 & 0.001 & -0.004 & -0.026 & -0.011 & -0.089 & -0.019 \\
\hline Albion & $(0.029)$ & $(0.021)$ & $(0.087)$ & $(0.076)$ & (0.009) & $(0.001)^{* * *}$ & $(0.033)$ & $(0.081)$ & $(0.078)$ & $(0.056)$ \\
\hline \multirow[t]{2}{*}{ Watford } & 0.001 & -0.055 & 0.354 & -0.441 & -0.009 & 0.003 & 0.206 & -0.212 & 0.014 & -0.184 \\
\hline & $(0.079)$ & $(0.046)$ & $(0.513)$ & $(0.321)$ & $(0.043)$ & $(0.005)$ & $(0.147)$ & $(0.508)$ & $(0.248)$ & $(0.188)$ \\
\hline All teams & -0.018 & 0.093 & 0.165 & 0.184 & -0.007 & -0.002 & 0.204 & 0.220 & -0.022 & -0.061 \\
\hline pooled & $(0.017)$ & $(0.016)^{* * *}$ & $(0.108)$ & $(0.072)^{* *}$ & $(0.011)$ & $(0.001)^{* *}$ & $(0.053)^{* * * *}$ & $(0.102)^{* *}$ & $(0.067)$ & $(0.058)$ \\
\hline
\end{tabular}

Notes: Cell entries are parameter estimates with heteroscedasticity and autocorrelation-consistent standard errors in parentheses; *, ** and *** denote significance at the $10 \%, 5 \%$ and $1 \%$ levels respectively. 
Table 7: Results for the model incorporating the effect of lagged surprise results, strength rivalry with opposing team, proximity to end of season, and the lagged surprise in goal difference on stock returns

Model: $R_{t}=\alpha+\beta_{1} M_{t}+\beta_{2}\left(S_{t-1} F_{t-1} R V_{t-1}\right)+\beta_{3}\left(G S_{t-1} R V_{t-1}\right)+\varepsilon_{t}$

\begin{tabular}{|c|c|c|c|c|}
\hline Team & $\alpha$ & $\beta_{1}$ & $\beta_{2}$ & $\beta_{3}$ \\
\hline \multirow{2}{*}{ Aston Villa } & 0.043 & 0.108 & $\begin{array}{l}-0.002 \\
\end{array}$ & 0.0005 \\
\hline & $(0.038)$ & $(0.036) * * *$ & (0.004) & $(0.0003)$ \\
\hline \multirow[t]{2}{*}{ Birmingham } & 0.048 & 0.134 & 0.010 & 0.003 \\
\hline & $(0.061)$ & $(0.058)^{* *}$ & $(0.003)^{* * *}$ & $(0.003)$ \\
\hline \multirow{2}{*}{ Bolton } & -0.124 & 0.414 & 0.008 & -0.005 \\
\hline & $(0.182)$ & $(0.139) * * *$ & (0.009) & (0.006) \\
\hline \multirow{2}{*}{ Charlton } & 0.0005 & -0.008 & 0.004 & 0.0004 \\
\hline & (0.044) & (0.051) & (0.008) & (0.003) \\
\hline \multirow{2}{*}{ Chelsea } & 0.114 & 0.303 & -0.013 & 0.010 \\
\hline & (0.154) & $(0.129)^{* *}$ & $(0.017)$ & (0.008) \\
\hline \multirow[t]{2}{*}{ QPR } & -0.015 & 0.552 & 0.014 & -0.049 \\
\hline & $(0.258)$ & $(0.488)$ & (0.010) & $(0.025)^{* *}$ \\
\hline \multirow{2}{*}{ Leeds } & -0.170 & 0.180 & 0.012 & 0.004 \\
\hline & $(0.157)$ & $(0.100) *$ & $(0.013)$ & (0.009) \\
\hline \multirow[t]{2}{*}{ Leicester } & -0.175 & -0.022 & 0.041 & -0.007 \\
\hline & $(0.166)$ & $(0.207)$ & $(0.021)^{* *}$ & $(0.007)$ \\
\hline \multirow[t]{2}{*}{ Man United } & 0.033 & 0.260 & -0.005 & 0.0004 \\
\hline & $(0.075)$ & $(0.070) * * *$ & $(0.007)$ & (0.004) \\
\hline \multirow[t]{2}{*}{ Millwall } & -0.122 & 0.081 & 0.004 & 0.001 \\
\hline & $(0.081)$ & $(0.067)$ & (0.005) & (0.004) \\
\hline \multirow[t]{2}{*}{ Newcastle } & 0.084 & 0.081 & 0.007 & -0.004 \\
\hline & $(0.057)$ & $(0.063)$ & (0.007) & (0.004) \\
\hline \multirow[t]{2}{*}{ Nottingham Forest } & -0.012 & -0.081 & -0.009 & -0.0009 \\
\hline & $(0.181)$ & $(0.122)$ & $(0.015)$ & (0.008) \\
\hline \multirow[t]{2}{*}{ Preston } & -0.028 & 0.004 & 0.002 & 0.0002 \\
\hline & $(0.016)^{*}$ & $(0.013)$ & (0.001) & $(0.001)$ \\
\hline \multirow[t]{2}{*}{ Sheffield United } & 0.007 & 0.128 & 0.008 & -0.008 \\
\hline & $(0.061)$ & $(0.055)^{* *}$ & (0.005) & $(0.005)$ \\
\hline \multirow[t]{2}{*}{ Southampton } & 0.002 & 0.021 & 0.022 & -0.007 \\
\hline & $(0.039)$ & $(0.035)$ & $(0.010)^{* *}$ & $(0.003) * * *$ \\
\hline \multirow[t]{2}{*}{ Sunderland } & -0.090 & 0.001 & 0.006 & -0.006 \\
\hline & (0.077) & $(0.066)$ & $(0.005)$ & $(0.004)^{*}$ \\
\hline \multirow[t]{2}{*}{ Tottenham Hotspur } & 0.044 & 0.042 & 0.010 & -0.0005 \\
\hline & $(0.035)$ & $(0.032)$ & $(0.010)$ & $(0.003)$ \\
\hline \multirow[t]{2}{*}{ West Brom. Albion } & 0.013 & -0.001 & -0.0008 & -0.004 \\
\hline & $(0.026)$ & $(0.021)$ & $(0.001)$ & $(0.001)^{* * *}$ \\
\hline \multirow[t]{2}{*}{ Watford } & -0.096 & -0.046 & 0.005 & 0.002 \\
\hline & $(0.076)$ & $(0.044)$ & $(0.006)$ & $(0.004)$ \\
\hline \multirow[t]{2}{*}{ All teams pooled } & -0.022 & 0.092 & 0.005 & -0.001 \\
\hline & $(0.016)$ & $(0.016)^{* * *}$ & $(0.001) * * *$ & $(0.0009)$ \\
\hline
\end{tabular}

Notes: Cell entries are parameter estimates with heteroscedasticity and autocorrelation-consistent standard errors in parentheses; $*$, ** and $* * *$ denote significance at the $10 \%, 5 \%$ and $1 \%$ levels respectively. 